\title{
Serological testing for antibodies against canine parvovirus in a population of adult dogs in eastern Poland
}

\author{
ALICJA WÓJCIK, JERZY ZIĘTEK, MARTA STANIEC, \\ RADOSŁAW JANECKI, ŁUKASZ ADASZEK, STANIS ŁAW WINIARCZYK
}

Department of Epizootiology and the Clinic of Infectious Diseases, Faculty of Veterinary Medicine, University of Life Sciences in Lublin, Głęboka 30, 20-612 Lublin, Poland

Wójcik A., Ziętek J., Staniec M., Janecki R., Adaszek Ł., Winiarczyk S. Serological testing for antibodies against canine parvovirus in a population of adult dogs in eastern Poland

\section{Summary}

The aim of the study was to determine the titre of antibodies against canine parvovirus in groups of adult dogs from eastern Poland with a varied history of vaccination against parvovirus. 200 dogs divided into three groups were included in the study. The first group $(n=59)$ consisted of subjects regularly vaccinated against the disease according to WSAVA guidelines. The second group $(n=77)$ consisted of animals that completed the full course of CPV immunisation as puppies but had not received a booster dose in the past three years. The third group $(n=64)$ consisted of animals that had not received even a single vaccination against parvovirus. Blood was collected from all dogs to determine the titres of antibodies against canine parvovirus using a Bionote V200 analyser (VetExpert). In group I, antibody titres equal to or higher than $\mathrm{HI}=\mathbf{8 0}$, thought of as ensuring resistance to infection were observed in $86 \%$ of dogs, while $14 \%$ of the tested animals had $\mathrm{HI}<80$. In groups II and III, high anti-CPV antibody titres of $\mathrm{HI}>80$ were found in $73 \%$ and $72 \%$ dogs, respectively. The large number of positive seroreactants with high titres of antibodies indicates the high immunogenicity of vaccine and field strains of canine parvovirus and common occurrence of canine parvovirus in the environment.

Keywords: canine parvovirus, dogs, vaccination, antibody titre

Canine parvovirus is a viral disease caused by CPV-2 (canine parvovirus type 2) parvovirus belonging to the family Parvoviridae, subfamily Parvovirinae, genus Protoparvovirus (18). The first cases of CPV-2 infection were recorded in the USA in 1978. The virus, due to its high contagiousness and low sensitivity to environmental conditions, quickly spread throughout the world. Over the years, canine parvovirus has evolved. Currently, three strains are distinguished, referred to as: CPV-2a, CPV-2b and CPV-2c (3), which are widely accepted to have almost completely replaced CPV-2 (13). Infection occurs in dogs through oral contact with the vomit or faeces of sick animals. Due to the high resistance of the parvovirus strains to environmental conditions, infection can occur not only through direct contact, but also indirectly - through contaminated items such as, for example, bowls or toys.

Canine parvovirosis is a systemic disease and the virus has a special affinity to rapidly dividing cells like bone marrow cells or enterocytes. After entering the body, the virus initially replicates in the lymphoid tissue of the throat, from where it spreads to the intestinal crypts. The typical symptoms of parvovirus include apathy, lack of appetite, vomiting and bloody diarrhoea $(5,11)$. The disease may lead to the death of infected animals (14). Not all dogs are equally susceptible to infection. Factors predisposing to the development of infection are age (puppies after the loss of maternal immunity, just before preventive vaccinations), stress (caused by poor hygiene conditions, high density, or, for example, changing the place of residence and being separated from the mother), and above all the lack of or incorrectly conducted vaccinations against this disease (12).

The most effective way of preventing parvovirus is prophylactic vaccination. However, our own observations show that recently some animal owners and veterinarians have withdrawn from booster vaccina- 
Tab. 1. Animals used in the study

\begin{tabular}{|c|c|c|c|c|c|}
\hline \multirow{2}{*}{$\begin{array}{c}\text { Titre } \\
\text { HI }\end{array}$} & \multirow{2}{*}{$\begin{array}{l}\text { Number } \\
\text { of dogs }\end{array}$} & \multirow{2}{*}{ Group } & \multicolumn{2}{|c|}{ Gender } & \multirow{2}{*}{ Breed } \\
\hline & & & M & $F$ & \\
\hline \multirow{3}{*}{$<10$} & 0 & I & - & - & - \\
\hline & 1 & II & 1 & - & mixed \\
\hline & 0 & III & - & - & - \\
\hline \multirow{3}{*}{20} & 5 & I & 3 & 2 & $\begin{array}{l}\text { German shepherd } n=1 \text {, } \\
\text { Maltese } n=1 \\
\text { Mixed } n=3\end{array}$ \\
\hline & 9 & II & 3 & 6 & $\begin{array}{l}\text { Husky } n=3, \\
\text { Mixed } n=4, \\
\text { Polish hound } n=1 \text {, } \\
\text { Shih-tzu } n=1\end{array}$ \\
\hline & 9 & III & 5 & 4 & $\begin{array}{l}\text { Mixed } n=7 \text {, } \\
\text { German shepherd } n=1 \text {, } \\
\text { Husky } n=1\end{array}$ \\
\hline \multirow{3}{*}{40} & 3 & I & 1 & 2 & $\begin{array}{l}\text { Mixed } n=2 \\
\text { Shar-pei } n=1\end{array}$ \\
\hline & 11 & II & 6 & 5 & $\begin{array}{l}\text { Cocker spaniel } n=1 \text {, } \\
\text { German shepherd } n=1 \\
\text { German wirehaired pointer } n=1 \text {, } \\
\text { Miniature schnauzer } n=1 \text {, } \\
\text { Mixed } n=4 \text {, } \\
\text { Parson russel terrier } n=1 \text {, } \\
\text { West highland white terrier } n=1 \text {, } \\
\text { Yorkshire terrier } n=1\end{array}$ \\
\hline & 9 & III & 3 & 6 & $\begin{array}{l}\text { Jack russel terrier } n=1 \text {, } \\
\text { Mixed } n=7 \text {, } \\
\text { Bullterrier } n=1\end{array}$ \\
\hline \multirow{3}{*}{80} & 7 & I & 3 & 4 & $\begin{array}{l}\text { German shepherd } n=2 \\
\text { Husky } n=1 \\
\text { Mixed } n=1 \\
\text { Pitbull terrier } n=1 \\
\text { Pug } n=1 \\
\text { Yorkshire terrier } n=1\end{array}$ \\
\hline & 13 & II & 8 & 4 & $\begin{array}{l}\text { American Staffordshire terrier } n=1 \text {, } \\
\text { German shepherd } n=1 \\
\text { Golden retriever } n=1 \text {, } \\
\text { Labrador retriever } n=2 \text {, } \\
\text { Mixed } n=5 \text {, } \\
\text { Samoyed } n=1 \text {, } \\
\text { Yorkshire terrier } n=1\end{array}$ \\
\hline & 9 & III & 7 & 2 & $\begin{array}{l}\text { German shepherd } n=1 \\
\text { Mixed } n=7 \\
\text { Yorkshire terrier } n=1\end{array}$ \\
\hline \multirow{3}{*}{160} & 17 & I & 12 & 5 & $\begin{array}{l}\text { Bernese } n=1 \text {, } \\
\text { Chinese crested } \operatorname{dog} n=1 \text {, } \\
\text { French bulldog } n=1 \text {, } \\
\text { Irish setter } n=1 \text {, } \\
\text { Jack russel terrier } n=1 \\
\text { Mixed } n=8 \text {, } \\
\text { West highland white terrier } n=2 \text {, } \\
\text { Yorkshire terrier } n=1\end{array}$ \\
\hline & 21 & II & 10 & 11 & $\begin{array}{l}\text { American Staffordshire terrier } n=1 \text {, } \\
\text { Central Asian Shepherd Dog } n=1 \text {, } \\
\text { Boxer } n=1 \text {, } \\
\text { German shepherd } n=4 \text {, } \\
\text { Husky } n=1 \text {, } \\
\text { Labrador retriever } n=1 \text {, } \\
\text { Mixed } n=11 \text {, } \\
\text { Yorkshire terrier } n=1\end{array}$ \\
\hline & 12 & III & 4 & 8 & $\begin{array}{l}\text { Labrador retriever } n=1 \text {, } \\
\text { Mixed } n=6 \text {, } \\
\text { Tatra Sheepdog } n=1 \\
\text { Yorkshire terrier } n=2 \text {, } \\
\text { Beagle } n=1 \text {, } \\
\text { German shepherd } n=1\end{array}$ \\
\hline
\end{tabular}

\begin{tabular}{|c|c|c|c|c|c|}
\hline \multirow{2}{*}{$\begin{array}{c}\text { Titre } \\
\text { HI }\end{array}$} & \multirow{2}{*}{$\begin{array}{l}\text { Number } \\
\text { of dogs }\end{array}$} & \multirow{2}{*}{ Group } & \multicolumn{2}{|c|}{ Gender } & \multirow{2}{*}{ Breed } \\
\hline & & & M & $\mathbf{F}$ & \\
\hline \multirow{3}{*}{$\begin{array}{l}320- \\
-640\end{array}$} & 13 & I & 6 & 7 & $\begin{array}{l}\text { German Shepherd } n=1 \text {, } \\
\text { German Shorthaired Pointer } n=1 \text {, } \\
\text { Husky } n=1 \text {, } \\
\text { Maltese } n=1 \text {, } \\
\text { Mixed } n=9\end{array}$ \\
\hline & 18 & II & 6 & 12 & $\begin{array}{l}\text { German shepherd } n=1 \text {, } \\
\text { German shorthaired pointer } n=1 \text {, } \\
\text { Irish setter } n=1 \text {, } \\
\text { Jack russel terrier } n=1 \text {, } \\
\text { Maltese } n=1 \text {, } \\
\text { Mixed } n=9 \text {, } \\
\text { White Swiss shepherd } n=1 \\
\text { Yorkshire terrier } n=1\end{array}$ \\
\hline & 13 & III & 4 & 9 & $\begin{array}{l}\text { Husky } n=1 \\
\text { Mixed } n=12\end{array}$ \\
\hline \multirow{3}{*}{$1280 \sim$} & 14 & I & 5 & 9 & $\begin{array}{l}\text { German Shepherd } n=2, \\
\text { Jack Russel Terrier } n=1 \text {, } \\
\text { Maltese } n=1 \text {, } \\
\text { Mixed } n=7, \\
\text { Pug } n=1 \text {, } \\
\text { Shiba inu } n=1 \text {, } \\
\text { Yorkshire terrier } n=1\end{array}$ \\
\hline & 4 & II & 1 & 4 & $\begin{array}{l}\text { Jack russel terrier } \mathrm{n}=1 \text {, } \\
\text { Mixed } \mathrm{n}=1 \text {, } \\
\text { Little Munsterlander } \mathrm{n}=1 \text {, } \\
\text { West highland white terrier } \mathrm{n}=1\end{array}$ \\
\hline & 12 & III & 4 & 9 & $\begin{array}{l}\text { Cane corso } n=1 \text {, } \\
\text { Mixed } n=11 \text {, } \\
\text { Yorkshire terrier } n=1\end{array}$ \\
\hline
\end{tabular}

tions, which is motivated by the high immunogenicity of vaccines against canine parvovirus, and the alleged lack of need to revaccinate animals that have undergone a complete vaccination course as puppies.

The aim of the study was to determine the titre of antibodies against CPV in groups of adult dogs from eastern Poland with varied history of vaccination against parvovirus.

\section{Material and methods}

Animals used in the study. The study was performed in the years 2017-2019. It involved 200 dogs (105 males and 95 females) of various breeds, aged 4-17 years (Tab. 1). Based on the history of vaccination against CPV, the animals were divided into three groups. The first group $(n=59)$ consisted of subjects regularly vaccinated against the disease according to WSAVA guidelines (https://www. wsava.org/Global-Guidelines/Vaccination-Guidelines). The second group $(\mathrm{n}=77)$ consisted of animals that completed the full course of CPV immunisation as puppies but had not received a booster dose in the past three years. The third group $(n=64)$ consisted of animals that had not received even a single vaccination against parvovirus. None of the dogs had a history of parvovirus. All animals included in the study were clinically healthy and did not take any medications. The reason for bringing the animals to the clinic were preventive check-ups (general health assessment and deworming). The owners of all animals agreed to have blood taken from the dogs. 
Serological examination. The blood for testing was collected from the cephalic vein and then centrifuged $(1500 \mathrm{~g})$. Serum was frozen $\left(-20^{\circ} \mathrm{C}\right)$ and stored until analysis.

The determination of titres of antibodies against CPV-2 was performed with the Bionote V200 analyser (VetExpert). The study was based on an indirect immunoenzymatic assay. It is validated by the manufacturer in relation to the 'gold standard' haemagglutination inhibition test. $5 \mu \mathrm{l}$ of the tested serum was added to the reagent provided by the manufacturer and thoroughly mixed. 4 drops of the obtained mixture were placed in the designated place on the test cassette and incubated for 10 minutes. At that time, a control line appeared on the test strip, confirming the correctness of the test, and then the test line. The concentration of antibodies against canine parvovirus for each sample was measured using the analyser, which checked the colour intensity of the test field. According to data provided by the manufacturer, the sensitivity calculated for CPV is $100 \%$ using the positive group and $88 \%$ using all sera samples. The specificity calculated for CPV is $100 \%$ using the positive sera group and 100\% using all sera samples (http:// biogal.co.il/wp-content/uploads/2013/02/SSCVV120213-. pdf). The protective titre of antibodies against parvovirus in the haemagglutination inhibition test was considered to be $>1: 80(4,7,15)$.

Statistical analysis. The Chi square test was used to demonstrate the differences in the anti-CPV-Ig titre between the studied groups of dogs (including the history of vaccination against $\mathrm{CPV}$, gender and breed of the dogs). Changes were considered statistically significant at $p<0.05$. The Statistica10.0 PL software was used for the calculations.

\section{Results and discussion}

In the first group, consisting of dogs vaccinated according to WSAVA guidelines, antibody titres equal to or higher than $\mathrm{HI}=80$, determining resistance to infection, were observed in $86 \%$ of dogs, while in $14 \%$ of the study animals, the antibody titres were $\mathrm{HI}<80$. In the second and third groups, high anti-CPV antibody titres of $\mathrm{HI}>80$ were found in $73 \%$ and $72 \%$ of dogs, respectively (Tab. 2).

In the pure-breed dogs group, the number of individuals with anti-parvovirus antibody titres ensuring protection against infection was $67(78 \%)$, while in the mixed-breed group it was $86(75 \%)$ In the group of males, high titres of antibodies against CPV were observed in $73(77 \%)$ of dogs, while in the group of females - in 80 (76\%) (Tab. 3).

Statistical analysis showed a significantly greater number of dogs with high titres of antibodies against $\mathrm{CPV}$ of $\mathrm{HI}>80$ in group I compared to the other two groups $(p=0.0006, p=0.0001$, respectively). Similarly, in group II, there were significantly more dogs with protective levels of antibodies than in group III $(p<0.00001)$. However, gender and race were not found to influence the value of titres of antibodies against $\mathrm{CPV}$.

Canine parvovirosis is a serious disease leading to the development of severe enteritis, which if left un-
Tab. 2. Values of antibody titre in HI test for CPV in dogs from particular groups in the study; number (\%)

\begin{tabular}{|c|c|c|c|}
\hline \multirow{2}{*}{ Titre HI } & \multicolumn{3}{|c|}{ Number (\%) of dogs in } \\
& $\begin{array}{c}\text { Group I } \\
\mathrm{n}=59\end{array}$ & $\begin{array}{c}\text { Group II } \\
\mathrm{n}=77\end{array}$ & $\begin{array}{c}\text { Group III } \\
\mathrm{n}=64\end{array}$ \\
\hline $\mathrm{HI}<80$ & $8(14)$ & $21(27)$ & $18(28)$ \\
$\mathrm{HI} \geq 80$ & $51(86)$ & $56(73)$ & $46(72)$ \\
\hline
\end{tabular}

Tab. 3. Values of antibody titre for CPV in the group of purebreed, mixed-breed, male and female dogs used in the study; number (\%)

\begin{tabular}{|c|c|c|c|c|}
\hline \multirow{2}{*}{ Titre HI } & \multicolumn{4}{|c|}{ Number (\%) of dogs in group } \\
& Mixed-breed & Pure-breed & Males & Females \\
\hline HI $<80$ & $28(25)$ & $19(22)$ & $22(23)$ & $25(24)$ \\
HI $\geq 80$ & $86(75)$ & $67(78)$ & $73(77)$ & $80(76)$ \\
\hline
\end{tabular}

treated, an infected dog may die. Due to the introduction of preventive vaccinations, the number of cases of parvovirus has been significantly reduced, although it has not been completely eradicated. The aim of the study was to conduct serological monitoring in the population of adult dogs from eastern Poland for the presence of antibodies against canine parvovirus in their serum.

Determination of titres of antibodies against canine parvovirus can be useful in the rational planning of vaccination of animals and in assessing the epizootic status of parvovirus in a given area $(6,21)$.

In our research, taking into account the history of immunoprophylaxis, the studied dogs were divided into three groups: group I - dogs vaccinated according to WSAVA recommendations (full course of primary vaccinations, then booster vaccinations at least every 3 years); group II - dogs vaccinated as puppies; group III - dogs never subjected to immunoprophylaxis. It was demonstrated that in all groups, there was a large number of animals with high titres of antibodies against parvovirus ( $\mathrm{HI}>80)$, considered as providing immunity against the disease $(16,17)$ (group I - 86\% dogs, group II $-73 \%$, group III $-72 \%$ ).

While this is not surprising for dogs from group I who have been exposed to the vaccine on a regular basis, the presence of a significant amount of positive seroreactants in group II, which includes dogs vaccinated for parvovirus as puppies, seems to confirm the high immunogenicity of canine parvovirus which is contained in the vaccines. For this reason, even dogs that have come into contact with the vaccine just once are able to develop immunity against infection with a fully virulent pathogen that has persisted for many years, which also has an impact on the maintenance of herd immunity among susceptible animals (19). These observations are consistent with studies by Twark and Dodds (21), Böhm (2) and Abdelmagid (1), according to which even a single vaccination of puppies against CPV stimulates immunity against parvovirus for an ex- 
tended period, lasting even 4-7 years. This is due to the natural strengthening of immunity through contact with the virus being widespread in the environment (10). The common presence of canine parvovirus results from its high resistance to environmental conditions, which allow it to remain virulent under favourable conditions (no exposure to sunlight, humid environment) for up to 12 months outside the host body $(8,20)$.

The presence of dogs with high titres of antibodies against canine parvovirus in group III may be a consequence of their contact with the field virus and indicates widespread contamination of the environment with this pathogen (2).

According to our own observations, regular vaccinations in accordance with WSAVA recommendations increase protection against parvovirus, as evidenced by the lowest percentage of dogs with $\mathrm{HI}<80$ in group I - dogs vaccinated at least every 3 years. However, it should be noted that despite regular immunoprophylaxis, $14 \%$ of animals in this group did not show antibody titres that could guarantee protection against infection with fully virulent CPV-2. The ineffectiveness of vaccinations may result from many factors, such as, e.g.: vaccine administration errors, storage errors, individual factors that do not allow the development of full immunity after vaccination, too long intervals between revaccinations, and others (9). Thus, serological tests allow the level of immunity against canine parvovirus in a given animal to be assessed and indicate the possible need to modify its vaccination plan, as well as the need for special treatment and isolation of animals unable to develop resistance to this virus.

The results of our research allow for drawing two conclusions. First, they indicate widespread environmental contamination with canine parvovirus, which is confirmed by the large number of positive seroreactants with high titres of antibodies against CPV in the population of dogs that have never been vaccinated against this virus - this shows that they must have encountered a field virus. Second, vaccination of dogs against the parvovirus disease, even if performed only once as a puppy, induces strong protection against infection, manifested by the persistence of high titres of antibodies against canine parvovirus in the serum of vaccinated animals for a long time, which is a consequence of significant immunogenicity of this virus.

The use of serological tests for parvovirus seems to be of crucial importance for medical and veterinary practice. In line with the principles of evidence-based veterinary medicine, testing the immune status (of both puppies and adults) is more beneficial than giving booster doses of vaccines, and minimises, among other things, the risk of developing vaccine-related adverse reactions. Additionally, the demonstration of positive seroreactants for canine parvovirus in the population of dogs allows the epizootic status of parvovirus in a given area to be assessed.

\section{References}

1.Abdelmagid O. Y, Larson L., Payne L., Tubbs A., Wasmoen T., Schultz R.: Evaluation of the efficacy and duration of immunity of a canine combination vaccine against virulent parvovirus, infectious canine hepatitis virus, and distemper virus experimental challenges. Vet. Ther. 2004, 5, 173-186.

2. Böhm M., Thompson H., Weir A., Hasted A. M., Maxwell N. S., Herrtage M. E.: Serum antibody titres to canine parvovirus, adenovirus and distemper virus in dogs in the UK which had not been vaccinated for at least three years. Vet. Rec. 2004, 154, 457-463.

3. Buonavoglia C., Martella V., Pratelli A., Tempesta M., Cavalli A., Buonavoglia D., Bozzo G., Elia G., Decaro N., Carmichael L.: Evidence for evolution of canine parvovirus type 2 in Italy. J. Gen. Virol. 2001, 82, 3021-3025.

4. Carmichael L. E., Joubert J. C., Pollack R. V.: Hemagglutination by canine parvovirus: serologic studies and diagnostic applications. Am. J. Vet. Res. 1980, 41, 784-791.

5. Castro T. X., Miranda S. C., Labarthe N. V., Silva L. E., Cubel Garcia R. C. N.: Clinical and epidemiological aspects of canine parvovirus (CPV) enteritis in the State of Rio de Janeiro: 1995-2004. Arq. Bras. Med. Veterinária E Zootec. 2007, 59, 333-339.

6. Decaro N., Buonavoglia C., Barrs V. R.: Canine parvovirus vaccination and immunisation failures: Are we far from disease eradication? Vet. Microbiol. 2020, 247, 108760 .

7. Decaro N., Desario C., Campolo M., Elia G., Martella V., Ricci D., Lorusso E., Buonavoglia $C$.: Clinical and virological findings in pups naturally infected by canine parvovirus type 2 Glu-426 mutant. J. Vet. Diagn. Invest. 2005, 17 , 133-138.

8. Gordon J. C., Angrick E. J.: Canine parvovirus: environmental effects on infectivity. Am. J. Vet. Res. 1986, 47, 1464-1467.

9. Heininger U., Bachtiar N. S., Bahri P., Dana A., Dodoo A., Gidudu J., Matos dos Santos E.: The concept of vaccination failure. Vaccine 2012, 30, 1265-1268.

10. Jiang F.: Bioclimatic and altitudinal variables influence the potential distribution of canine parvovirus type 2 worldwide. Ecol. Evol. 2018, 8, 4534-4543.

11. Kalli I., Leontides L. S., Mylonakis M. E., Adamama-Moraitou K., Rallis T., Koutinas A. F.: Factors affecting the occurrence, duration of hospitalisation and final outcome in canine parvovirus infection. Res. Vet. Sci. 2010, 89, 174-178

12. Larson L. J., Schultz R. D.: Do two current canine parvovirus type 2 and $2 \mathrm{~b}$ vaccines provide protection against the new type 2c variant? Vet. Ther. 2008, 9, 94-101.

13. Miranda C., Thompson G.: Canine parvovirus: the worldwide occurrence of antigenic variants. J. Gen. Virol. 2016, 97, 2043-2057.

14. Nandi S., Kumar M.: Canine parvovirus: current perspective. Indian J. Virol. 2010, 21, 31-44.

15. Pollack R. V. H., Carmichael L. E.: Maternally derived immunity to canine parvovirus infection: transfer, decline, and interference with vaccination. J. Am. Vet. Med. Assoc. 1982, 180, 37-42.

16. Pollock R. V. H., Carmichael L. E.: Dog response to inactivated canine parvovirus and feline panleukopenia virus vaccines. Cornell Vet. 1982a, 72, 16-35.

17. Pollock R. V. H., Carmichael L. E.: Maternally derived immunity to canine parvovirus infection: transfer, decline, and interference with vaccination. J. Am. Vet. Med. Assoc. 1982b, 180, 37-42.

18. Ros C., Bayat N., Wolfisberg R., Almendral J. M.: Protoparvovirus Cell Entry. Viruses 2017, 9, 313.

19. Schultz R. D., Thiel B., Mukhtar E., Sharp P., Larson L. J.: Age and longterm protective immunity in dogs and cats. J. Comp. Pathol. 2010, 142 Suppl 1:S102-8.

20. Sykes J. E.: Canine parvovirus infections and other viral enteritides, [in:] Canine and Feline Infectious Diseases. $1^{\text {st }}$ ed. St Louis, MO: Elsevier 2014, p. 141-151.

21. Twark L., Dodds W. J.: Clinical use of serum parvovirus and distemper virus antibody titers for determining revaccination strategies in healthy dogs. J. Am. Vet. Med. Assoc. 217, 1021-1024.

Corresponding author: Alicja Wójcik, DVM, Department of Epizootiology and the Clinic of Infectious Diseases, Faculty of Veterinary Medicine, University of Life Sciences in Lublin, Glęboka 30, 20-612 Lublin, Poland; e-mail: lis.alicja@gmail.com 